\title{
Coffee pulp compost: Chemical properties and distribution of humic substances ${ }^{1,2}$
}

\author{
Joaquín A. Chong ${ }^{3}$ and José A. Dumas ${ }^{4}$
}

J. Agric. Univ. P.R. 96(1-2):77-87 (2012)

\begin{abstract}
The distribution and chemical properties of humic substances (humic acids and fulvic acids) from a twelve-month-old static aerated compost pile of coffee pulp were studied. The compost was separated into five physical granule fractions $(500,1000,2000,4000$ and $8000 \mu \mathrm{m})$ in order to determine the effect of particle size on humic substances, on nutrient composition, and on distribution. The objective of this study was to understand the chemical properties and distribution of humic substances in mature coffee pulp compost. There were no significant differences across fractions for total $\mathrm{N}$ and available $\mathrm{P}_{2} \mathrm{O}_{5}$; these fractions averaged 4.9 and $0.66 \%$, respectively. Potassium (K) increased as fraction size increased, from 3.01 to $3.94 \%$. Readily available nitrogen, $\mathrm{NO}_{3}$ and $\mathrm{NH}_{4}$, was $7.19 \%$ of the total N. Eightynine percent of the total $\mathrm{K}$ was exchangeable $\mathrm{K}$ ions, and these varied within compost fractions from 2.82 to $3.33 \%$. Approximately $50 \%$ of the total $\mathrm{Ca}$ and $\mathrm{Mg}$ were exchangeable ions; $\mathrm{Ca}$ ions varied from 2.13 to $3.01 \%$, and $\mathrm{Mg}$ ions varied from 0.22 to $0.26 \%$ among fractions. Sequential extraction of organic carbon showed higher extractable carbon by the extraction with $0.1 \mathrm{~N} \mathrm{NaOH}$ for $24 \mathrm{~h}$, followed by $0.1 \mathrm{~N} \mathrm{NaOH}$ for $2 \mathrm{~h}$, and water for $2 \mathrm{~h}$. The optical densities E4/E6 ratio ranged between 6.6 and 8.5 for humic acids (HA) extracted with $\mathrm{NaOH}$ for $2 \mathrm{~h}$. The diversity in humic substances (HS) and exchangeable ions among compost fractions indicates that nutrient release is regulated by the size of the granules. In conclusion, these data demonstrate that smaller size particles have greater humification rates, and that $\mathbf{N}$ and available $\mathbf{P}$ are similar across particle sizes, thus providing an excellent soil compost amendment.
\end{abstract}

Key words: humic acids, fulvic acids, organic carbon, sequential extraction

${ }^{1}$ Manuscript submitted to the Editorial Board 6 September 2011.

${ }^{2}$ We recognize and are grateful for the funding of this research project provided by NRCS-Conservation Innovation Grants, and by the Agricultural Experiment Station, University of Puerto Rico.

${ }^{3}$ Plant Physiologist, Assistant Researcher, Department of Crops and Agroenvironmental Sciences, Agricultural Experiment Station, University of Puerto Rico, 1193 Calle Guayacán, Jardín Botánico Sur, San Juan, Puerto Rico, 00926-1118. Telephone: (787)767-9705 x 2208 (voice); Fax: (787)753-2712; Email: joaquin.chong@upr.edu

${ }^{4}$ Chemist, Department of Crops and Agroenvironmental Sciences, Agricultural Experiment Station, University of Puerto Rico, 1193 Calle Guayacán, Jardín Botánico Sur, San Juan, Puerto Rico, 00926-1118. Telephone: (787)767-9705 x 2242 (voice); Fax: (787)753-2712; Email: josea.dumas@upr.edu 


\section{RESUMEN \\ Composta de pulpa de café: Propiedades químicas y distribución de substancias húmicas}

Se estudiaron las propiedades químicas y sustancias húmicas (ácidos húmicos y ácidos fúlvicos) de composta de pulpa de café de 12 meses; esta fue compostada en una pila estática aireada. La composta se dividió en cinco fracciones físicas de gránulos $(500,1000,2000,4000$ y $8000 \mu \mathrm{m})$ con el fin de determinar el efecto del tamaño de las partículas en la cantidad de sustancias húmicas, composición de nutrientes, y distribución. El objetivo de este estudio fue entender las propiedades químicas y distribución de substancias húmicas en composta madura de pulpa de café. No hubo diferencias significativas entre las fracciones para $\mathrm{N}$ total y $\mathrm{P}_{2} \mathrm{O}_{5}$ disponible; el promedio fue de 4.9 y $0.66 \%$, respectivamente. El potasio $(\mathrm{K})$ aumentó de $3.01 \%$ a un $3.94 \%$ a medida que aumentó el tamaño de la fracción. Nitrógeno disponible, $\mathrm{NO}_{3}$ y $\mathrm{NH}_{4}$, representó $7.19 \%$ del total de $\mathrm{N}$. Un $89 \%$ del $\mathrm{K}$ total estaba en forma intercambiable y solo varió de 2.82 a $3.33 \%$. Aproximadamente el $50 \%$ del total de Ca y $\mathrm{Mg}$ estaba en forma intercambiable. La concentración del ion de $\mathrm{Ca}$ varió de 2.13 a $3.01 \%$, y la del el ion de $\mathrm{Mg}$ varió de 0.22 a $0.26 \%$ entre las fracciones. La extracción secuencial de carbono orgánico fue mayor para el extractante $0.1 \mathrm{~N} \mathrm{NaOH}$ por $24 \mathrm{~h}$, seguido por $0.1 \mathrm{~N} \mathrm{NaOH}$ por $2 \mathrm{~h}$ y finalmente agua por $2 \mathrm{~h}$. La relación de densidades ópticas E4/E6 osciló entre 6.6 y 8.5 para ácidos húmicos que se extrajeron con $\mathrm{NaOH}$ durante $2 \mathrm{~h}$. La diversidad en sustancias húmicas e iones intercambiables entre fracciones indica que la liberación de nutrientes está regulada por el tamaño de los gránulos. En conclusión, estos datos demuestran que las partículas más pequeñas tienen mayores tasas de humificación, y que el $\mathrm{N}$ y $\mathrm{P}$ disponible son similares en todos los tamaños de las partículas. Estos resultados demuestran que la utilización de compostas es un método excelente para proveer nutrientes al suelo, y que la pulpa de café bien compostada puede convertirse en un recurso para las fincas agrícolas.

Palabras clave: ácidos húmicos, ácidos fúlvicos, carbón orgánico, extracción secuencial

\section{INTRODUCTION}

Coffee is the major agricultural industry in Puerto Rico, covering 57,000 acres in 14 municipalities in the humid central mountain region (Alamo et al., 2006). According to statistics from the Department of Agriculture of Puerto Rico, during the year 2007-2008 coffee production amounted to 7,500 tons of coffee beans at a farm value of over $\$ 36.5$ million US dollars. Assuming $41 \%$ of coffee pulp (CP) and $20 \%$ coffee bean by weight, the estimated CP for that year was 15,375 tons.

Coffee pulp is a by-product obtained from coffee processing; it is a wet feedstock with 85 to $95 \%$ water content. The CP has a high concentration of nutrients with a strong potential to impair water resources. Farmers perceive this organic byproduct as waste that needs to be processed at extra cost and effort; hence there is a willingness to remove it from their farms. Coffee pulp composition is basically carbohydrates 
(210 to $320 \mathrm{~g} / \mathrm{kg}$ ), proteins ( 75 to $150 \mathrm{~g} / \mathrm{kg}$ ) and fats (20 to $70 \mathrm{~g} / \mathrm{kg}$ ) (Ulloa-Rojas et al., 2003; Fischer et al., 2001; Murkovic et al., 2006). Additionally it contains 2 to $9 \%$ total tannins, 0.8 to $2.8 \%$ of which are soluble tannins; $7 \%$ pectins; $1 \%$ caffeine; $3 \%$ chlorogenic acid (CGA); and $2 \%$ caffeic acids (Farah et al., 2006).

The amount and chemical forms (aliphatic and aromatic structures) of humic substances can be used to evaluate the long-term effects of the compost soil amendment. The proportion of aromatic carbon structures, measured by optical densities at $465 \mathrm{~nm}$ (E4) and $665 \mathrm{~nm}$ (E6), provides an indication of recalcitrant, stable non water-soluble, versus the aliphatic structure chain, which is water soluble and subject to labile pressures. This finding is important because it provides a degree of maturity of the humic substances (HS) (Tan, 2003). The HS chemical properties could be different among compost particles in a static pile. This difference could affect the short- and long-term agronomic benefits from humic compost on the soils.

One main objective of this study was to evaluate the chemical and physical properties of the particle sizes of coffee pulp (CP) compost obtained from an aerobic static process, including nutrient content. Another objective was to evaluate the labile and non-labile organic carbon distribution in the compost particle sizes to quantify the benefits of composted coffee pulp. This evaluation can provide an additional incentive for farmers to implement on-farm compost practices.

\section{MATERIALS AND METHODS}

Twelve-month-old coffee pulp from a static aerated compost pile was prepared at a compost pilot plant at the Adjuntas Agricultural Experiment Station using $6.6 \mathrm{~m}^{3}$ of coffee pulp per $\mathrm{m}^{3}$ of coffee parchment as an aeration compost base (Chong, 2009). Compost samples were collected in December 2008 after screening compost through a 0.95-cm screen (Orbit model 62, Delhi, IA). The samples were then passed through 8000-, 4000-, 2000-, 1000-, and 500-um sieves. Three replicate sieved samples were then placed and tied up in plastic bags and delivered the next day for laboratory testing. The compost fractions were analyzed for $\mathrm{pH}$ and electrical conductivity (1:5 compost: water ratio). Total organic carbon (TOC) content was determined by the Walkley and Black method (Nelson and Sommers, 1996). All data were expressed relative to dried mass.

Total Kjeldahl $\mathrm{N}$ and $\mathrm{P}$ and inorganic nitrogen $\left(\mathrm{N}-\mathrm{NH}_{4}\right.$ and $\left.\mathrm{N}-\mathrm{NO}_{3}\right)$ were measured with an Autoanalyzer Technicon II (ATII). Inorganic nitrogen was extracted by shaking $0.5 \mathrm{~g}$ of fresh compost with $30 \mathrm{ml}$ of 
$2 \mathrm{~N} \mathrm{KCl}$ for $30 \mathrm{~min}$. Available $\mathrm{P}$ was obtained by using AOAC method 960.02. With this method the available $P$ was calculated by subtracting citrate-insoluble $\mathrm{P}$ from total $\mathrm{P}$. Total $\mathrm{K}, \mathrm{Ca}$ and $\mathrm{Mg}$ of composts were extracted by the dry ash method and determined with a TJA atomic absorption spectrophotometer (AAS). Exchangeable $\mathrm{K}, \mathrm{Ca}$, and $\mathrm{Mg}$ were extracted with $1 \mathrm{~N} \mathrm{NH}_{4} \mathrm{OAc}(\mathrm{pH} 7)$ and were determined with AAS. Blank samples were used during the extraction procedure to correct for background contamination.

The humic acids (HA) and fulvic acids (FA) were sequentially extracted by the method of $\mathrm{Wu}$ and $\mathrm{Ma}$ (2002). The extraction was performed sequentially by using 10 to $100 \mathrm{w} / \mathrm{v}$ of compost to extracting solution. Samples were first extracted with water for $2 \mathrm{~h}$, followed by a $0.1 \mathrm{~N} \mathrm{NaOH}$ solution for $2 \mathrm{~h}$ and $24 \mathrm{~h}$, respectively. Compost suspensions were shaken at room temperature and then centrifuged at 3000 rpm for $10 \mathrm{~min}$. The solution was then filtered through a 0.45 nylon membrane. An aliquot of this filtered solution $(50 \mathrm{ml})$ was adjusted to $\mathrm{pH}<2$ with $12 \mathrm{~N} \mathrm{HCl}$, and then centrifuged at $10,000 \mathrm{rpm}$ and filtered through a $0.45-\mu m$ nylon membrane. The HA was the solid, whereas the FA was in solution. The HA and FA were added for total HS. Organic carbon (OC) concentrations were determined with a Dohrmann TOC D190 carbon analyzer from the FA solution, and for HA after the HA pellet was re-dissolved in $50 \mathrm{ml}$ of $0.1 \mathrm{~N} \mathrm{NaOH}$.

The UV-Vis spectrum of HA solutions, $200 \mathrm{mg} / \mathrm{L}$ in $0.05 \mathrm{M} \mathrm{NaHCO}_{3}$, were measured by using a UV-Vis Beckman spectrometer at a range of 700 to $190 \mathrm{~nm}$. The optical densities at $465 \mathrm{~nm}$ (E4) and at $665 \mathrm{~nm}$ (E6) were recorded. These values were used for calculation of the E4/ E6 ratio (Chen et al., 1977; Amir et al., 2003).

Data collected from each fraction size were analyzed statistically by using SAS. Analysis of variance (ANOVA) was performed to evaluate the effects of compost granule sizes. Significant means were separated by least significant difference (LSD) tests at $\mathrm{P} \leq 0.05$.

\section{RESULTS AND DISCUSSION}

\section{Nutrient analysis}

No fractions showed any significant differences for total $\mathrm{N}$ and $\mathrm{P}$ values; however, total $\mathrm{K}$ varied from 3.01 to $3.94 \%$ (Table 1). Averaged across fractions, total $\mathrm{N}$ was $4.89 \%$, and it ranged from 4.29 to $5.31 \%$ having a standard deviation of $0.38 \%$. Out of the total $\mathrm{N}$, extractable $\mathrm{NO}_{3}$ ranged from 0.33 to $0.37 \%$, and $\mathrm{NH}_{4}$ nitrogen was less than a fraction of one percent. The organic $\mathrm{N}$ content averaged $92.9 \%$ across all fractions. Total $\mathrm{P}$ values averaged $0.46 \%$ and ranged from 0.43 to 
TABLE 1.-Nutrient composition of coffee pulp fractions.

\begin{tabular}{|c|c|c|c|c|c|c|c|c|}
\hline \multirow{2}{*}{$\begin{array}{l}\text { Compost fraction } \\
(\mu \mathrm{m})\end{array}$} & Total N & $\mathrm{N}-\mathrm{NO}_{3}$ & $\mathrm{~N}-\mathrm{NH}_{4}$ & $\begin{array}{c}\text { Total } \\
\mathrm{P} \\
\end{array}$ & $\begin{array}{c}\text { Available } \\
\mathrm{P}_{2} \mathrm{O}_{5}\end{array}$ & $\begin{array}{c}\text { Total } \\
\mathrm{K}\end{array}$ & $\mathrm{Ca}$ & $\mathrm{Mg}$ \\
\hline & \multicolumn{6}{|c|}{$\%$} & \multicolumn{2}{|c|}{$\%$} \\
\hline $\begin{array}{l}500 \\
1000\end{array}$ & $\begin{array}{l}4.81 \mathrm{a}^{1} \\
4.95 \mathrm{a}\end{array}$ & $\begin{array}{l}0.33 \mathrm{~b} \\
0.36 \mathrm{a}\end{array}$ & $\begin{array}{l}8.11 \times 10^{-4} \mathrm{~b} \\
1.01 \times 10^{-3} \mathrm{ab}\end{array}$ & $\begin{array}{l}0.43 \mathrm{a} \\
0.50 \mathrm{a}\end{array}$ & $\begin{array}{l}0.60 \mathrm{a} \\
0.75 \mathrm{a}\end{array}$ & $\begin{array}{l}3.01 \mathrm{c} \\
3.51 \mathrm{~b}\end{array}$ & $\begin{array}{l}4.71 \mathrm{~b} \\
5.27 \mathrm{a}\end{array}$ & $\begin{array}{l}0.46 \mathrm{c} \\
0.56 \mathrm{ab}\end{array}$ \\
\hline 2000 & $5.09 \mathrm{a}$ & $0.35 \mathrm{ab}$ & $9.41 \times 10^{-4} \mathrm{ab}$ & $0.44 \mathrm{a}$ & $0.65 \mathrm{a}$ & $3.48 \mathrm{~b}$ & $5.54 \mathrm{a}$ & $0.53 \mathrm{~b}$ \\
\hline 4000 & $4.29 \mathrm{a}$ & $0.37 \mathrm{a}$ & $1.11 \times 10^{-3} \mathrm{a}$ & $0.45 \mathrm{a}$ & $0.68 \mathrm{a}$ & $3.62 \mathrm{~b}$ & $5.19 \mathrm{ab}$ & $0.51 \mathrm{bc}$ \\
\hline 8000 & $5.31 \mathrm{a}$ & $0.33 \mathrm{~b}$ & $1.03 \times 10^{-3} \mathrm{ab}$ & $0.48 \mathrm{a}$ & $0.63 a$ & $3.94 \mathrm{a}$ & $5.09 \mathrm{ab}$ & $0.62 \mathrm{a}$ \\
\hline
\end{tabular}

${ }^{1}$ Within columns, means followed by the same letter are not significantly different at $\mathrm{P}<0.05$. 
$0.50 \%$; available phosphorous oxide $\left(\mathrm{P}_{2} \mathrm{O}_{5}\right)$, averaged $0.66 \%(0.30 \%$ of $\mathrm{P}$ ), which is $65 \%$ of the total, and had a standard deviation of $0.06 \%$.

Total $\mathrm{K}$ content increased with increasing fraction size. Potassium in mature compost is usually not incorporated into organic matter because it is highly soluble. Thus, potassium can easily move from fractions when the organic matter is mineralized, which explains the lower $\mathrm{K}$ content in the smallest fraction. Although not examined during this experiment, the aggregate distribution and amounts of different particle sizes could influence availability of nutrients.

The CEC was different among fractions, with the lowest average in the smallest fraction; it ranged from 203 to $262 \mathrm{cmol} / \mathrm{kg}$ (Table 2). In general, the exchangeable ions $\mathrm{K}, \mathrm{Ca}$ and $\mathrm{Mg}$ had some of the lowest content in the smallest fraction. The $\mathrm{Na}$ ion concentration had no significantly different values across all fractions (Table 2). On average, $89 \%$ of the total $\mathrm{K}$ was in the exchangeable form, which ranged from 2.82 to $3.33 \%$ among fractions. Total $\mathrm{Ca}$ content ranged from 4.71 to $5.54 \%$ and the exchangeable portion ranged from 2.13 to $3.01 \%$, being approximately $50 \%$ of the total $\mathrm{Ca}$. Similarly, total $\mathrm{Mg}$ content was between 0.46 and $0.62 \%$, and exchangeable $\mathrm{Mg}$ accounted for approximately $44.6 \%$ of the total $\mathrm{Mg}$ (Table 1 ). The CP fractions evaluated had no significant differences in electrical conductivity (EC), averaging $3.33 \mathrm{mS} / \mathrm{cm}$ (data not shown). The $\mathrm{pH}$ varied with no discerning trend, ranging from 6.72 to 6.84 (Table 3 ).

\section{Carbon analysis}

The TOC is comprised of biological carbon, which might include algae, mites, bacteria and fungi, plus humins, lignins, pectins, and humic substances (HS). The relationship between $\mathrm{C}$ and $\mathrm{N}$ quantities in compost is both an indication of maturity and an index of humification degree, which increases as the C:N ratio decreases (Marinari et al., 2007). The CP feedstock used in this study had a C:N ratio of $13: 1$. The $\mathrm{C}: \mathrm{N}$ ratio of the compost fractions ranged from 4.72:1 to 8.88:1 (Table 3).

TABLE 2.-Exchangeable nutrient content and cation exchange capacity of coffee pulp compost fractions.

\begin{tabular}{lccccccc}
\hline Compost fraction & & $\mathrm{CEC}$ & & $\mathrm{K}$ & $\mathrm{Ca}$ & $\mathrm{Mg}$ & $\mathrm{Na}$ \\
\cline { 5 - 8 } \cline { 5 - 7 }$(\mu \mathrm{m})$ & $\mathrm{cmolc} / \mathrm{kg}$ & & \multicolumn{3}{c}{$\%$} \\
\hline 500 & $203 \mathrm{c}^{1}$ & & $2.82 \mathrm{~b}$ & $2.13 \mathrm{~b}$ & $0.22 \mathrm{c}$ & $0.14 \mathrm{a}$ \\
1000 & $246 \mathrm{ab}$ & & $2.99 \mathrm{ab}$ & $2.88 \mathrm{a}$ & $0.23 \mathrm{~b}$ & $0.16 \mathrm{a}$ \\
2000 & $262 \mathrm{a}$ & & $3.33 \mathrm{a}$ & $3.01 \mathrm{a}$ & $0.24 \mathrm{~b}$ & $0.14 \mathrm{a}$ \\
4000 & $242 \mathrm{ab}$ & & $3.33 \mathrm{a}$ & $2.60 \mathrm{ab}$ & $0.24 \mathrm{ab}$ & $0.15 \mathrm{a}$ \\
8000 & $225 \mathrm{bc}$ & & $3.09 \mathrm{ab}$ & $2.34 \mathrm{~b}$ & $0.26 \mathrm{a}$ & $0.17 \mathrm{a}$ \\
\hline
\end{tabular}

${ }^{1}$ Within columns, means followed by the same letter are not significantly different at $\mathrm{P}<0.05$. 
TABLE 3.-The $p H$, total organic carbon and $C / N$ ratio at given coffee pulp compost fractions.

\begin{tabular}{llll}
\hline Granule size $\mu \mathrm{m}$ & $\mathrm{pH}$ & TOC \% & $\mathrm{C} / \mathrm{N}$ \\
\hline 500 & $6.78 \mathrm{~b}^{1}$ & $22.7 \mathrm{c}$ & 4.72 \\
1000 & $6.73 \mathrm{~cd}$ & $32.4 \mathrm{~b}$ & 6.54 \\
2000 & $6.72 \mathrm{~d}$ & $36.5 \mathrm{a}$ & 7.15 \\
4000 & $6.77 \mathrm{bc}$ & $38.1 \mathrm{a}$ & 8.88 \\
8000 & $6.84 \mathrm{a}$ & $38.5 \mathrm{a}$ & 7.25 \\
\hline
\end{tabular}

${ }^{1}$ Within columns, means followed by the same letter are not significantly different at $P \leq 0.05$.

The smallest fraction $(500 \mu \mathrm{m})$ had the lowest C:N ratio and TOC content, thus suggesting a greater humification in smallest fractions (Table 3). The TOC, which had the lowest quantities in the smallest fraction, $22.7 \%$, increased to $36.5 \%$ in the $2000-\mu \mathrm{m}$ fraction, and averaged $38.3 \%$; across the two larger fractions, between which there was no significant difference (Table 3 ).

The contact time had a strong effect on the extraction of HS with water and $0.1 \mathrm{M} \mathrm{NaOH}$. The HS in water ranged from 3.80 to $4.4 \mathrm{~g} /$ $\mathrm{kg}$ dry compost mass; $\mathrm{HS}$ in $0.1 \mathrm{M} \mathrm{NaOH}$ for $2 \mathrm{~h}$ ranged from 17.0 to $23.8 \mathrm{~g} / \mathrm{kg}$; HS in $0.1 \mathrm{~N} \mathrm{NaOH}$ for $24 \mathrm{~h}$ ranged from 38.0 to $47.6 \mathrm{~g} /$ $\mathrm{kg}$ dry compost mass. The above data showed that distribution of extractable $\mathrm{OC}$ across the three sequential extraction steps increased in the following order: water $<0.1 \mathrm{~N} \mathrm{NaOH}$ for $2 \mathrm{~h}<0.1 \mathrm{~N} \mathrm{NaOH}$ for $24 \mathrm{~h}$. This order corresponds mainly to an increase in the amount of humic acids (HA) rather than fulvic acids (FA) as indicated by the HA/FA distribution (Table 4). In general, HA of the compost granules extracted over a 24 -h period had lower E4/E6 values than HA extracted for $2 \mathrm{~h}$. This result indicates that a greater amount of less soluble and more recalcitrant HA was extracted by $0.1 \mathrm{M} \mathrm{NaOH}$ over a period of $24 \mathrm{~h}$. These results were supported by the value of HA/FA ratio, which was higher for organic matter from 24 -h extracts than from 2-h extracts (Table 4).

Greater amounts of total HS were obtained in larger particles; however, smaller particles had greater recalcitrance HS as shown by E4/ $\mathrm{E} 6$ ratio at $2 \mathrm{~h}$ (Table 5). Small particles arise from larger particles. As larger particles break down, the superficial area increases; thus, microorganisms have greater opportunity to decompose and increase the humified fractions of organic matter. Smaller particles have greater superficial area. This area is one of the reasons for their lower content of HS and higher HS/TOC ratio but greater aromatic HS. As larger particles became small, greater amounts of liable organic carbon were consumed and/or humified into aromatic humic substances. 
TABLE 4.-Organic carbon contents of sequentially extracted CP compost. Mass of compost is expressed on a dry weight basis.

\begin{tabular}{|c|c|c|c|c|c|c|c|c|c|c|c|c|}
\hline \multirow[b]{3}{*}{ Granule size $\mu \mathrm{m}$} & \multicolumn{4}{|c|}{ Water $2 \mathrm{~h}$} & \multicolumn{4}{|c|}{$0.1 \mathrm{M} \mathrm{NaOH} 2 \mathrm{~h}$} & \multicolumn{4}{|c|}{$0.1 \mathrm{M} \mathrm{NaOH} 24 \mathrm{~h}$} \\
\hline & $\mathrm{OC}_{\mathrm{FA}}$ & $\mathrm{OC}_{\mathrm{HA}}$ & $\mathrm{OC}_{\mathrm{FA}+\mathrm{HA}}$ & $\mathrm{HA} / \mathrm{FA}$ & $\mathrm{OC}_{\mathrm{FA}}$ & $\mathrm{OC}_{\mathrm{HA}}$ & $\mathrm{OC}_{\mathrm{FA}+\mathrm{HA}}$ & $\mathrm{HA} / \mathrm{FA}$ & $\mathrm{OC}_{\mathrm{FA}}$ & $\mathrm{OC}_{\mathrm{HA}}$ & $\mathrm{OC}_{\mathrm{FA}+\mathrm{HA}}$ & $\mathrm{HA} / \mathrm{FA}$ \\
\hline & $\ldots \ldots$ & $-\cdots g /$ & $\ldots \ldots$ & & $\ldots$ & $\ldots-\mathrm{g} / \mathrm{k}$ & $\ldots \ldots$ & & $\ldots$. & $\ldots \mathrm{g} / 1$ & $\ldots$ & \\
\hline $\begin{array}{l}500 \\
1000\end{array}$ & $\begin{array}{l}2.3 \mathrm{~b}^{1} \\
2.4 \mathrm{~b}\end{array}$ & $\begin{array}{l}1.5 \mathrm{c} \\
1.6 \mathrm{c}\end{array}$ & $\begin{array}{l}3.8 \\
4.0\end{array}$ & $\begin{array}{l}0.65 \\
0.67\end{array}$ & $\begin{array}{l}5.9 \mathrm{a} \\
6.3 \mathrm{a}\end{array}$ & $\begin{array}{l}15.3 \mathrm{~b} \\
17.5 \mathrm{a}\end{array}$ & $\begin{array}{l}21.2 \\
23.8\end{array}$ & $\begin{array}{l}2.58 \\
2.76\end{array}$ & $\begin{array}{l}9.3 \mathrm{c} \\
9.5 \mathrm{~b}\end{array}$ & $\begin{array}{l}28.7 \mathrm{e} \\
30.2 \mathrm{c}\end{array}$ & $\begin{array}{l}38.0 \mathrm{e} \\
39.7 \mathrm{c}\end{array}$ & $\begin{array}{l}3.07 \\
3.16\end{array}$ \\
\hline 2000 & $2.6 \mathrm{a}$ & $1.5 \mathrm{c}$ & 4.0 & 0.59 & $6.3 \mathrm{a}$ & $17.1 \mathrm{ab}$ & 23.4 & 2.71 & $9.6 \mathrm{~b}$ & $28.8 \mathrm{~d}$ & $38.4 \mathrm{~d}$ & 3.01 \\
\hline 4000 & $2.4 \mathrm{~b}$ & $1.8 \mathrm{~b}$ & 4.2 & 0.73 & $6.2 \mathrm{a}$ & $14.2 \mathrm{c}$ & 20.4 & 2.29 & $9.8 \mathrm{~b}$ & $33.1 \mathrm{~b}$ & $42.9 \mathrm{~b}$ & 3.37 \\
\hline 8000 & $2.4 \mathrm{~b}$ & $2.0 \mathrm{a}$ & 4.4 & 0.86 & $5.8 \mathrm{~b}$ & $11.3 \mathrm{~d}$ & 17.0 & 1.95 & $11.5 \mathrm{a}$ & $36.1 \mathrm{a}$ & $47.6 \mathrm{a}$ & 3.13 \\
\hline
\end{tabular}

${ }^{1}$ Within columns, means followed by the same letter are not significantly different at $P \leq 0.05$.

TABLE 5.-The total humic substances, extractable fulvic and humic acids, ratio of humic substances to total organic carbon, and absorbance of HA measured at $465 \mathrm{~nm}$ (E4) and $665 \mathrm{~nm}$ (E6) at given coffee pulp compost fractions.

\begin{tabular}{llllll}
\hline Granule size $\mu \mathrm{m}$ & HS $\%$ & FA $\%$ & HA \% & HS/TOC \% & HA NaOH 2h E4/E6 \\
\hline 500 & $6.07 \mathrm{c}^{1}$ & $1.74 \mathrm{c}$ & $4.33 \mathrm{c}$ & 26.8 & 7.50 \\
1000 & $6.76 \mathrm{ab}$ & $1.83 \mathrm{~b}$ & $4.93 \mathrm{ab}$ & 20.9 & 7.60 \\
2000 & $6.59 \mathrm{~b}$ & $1.85 \mathrm{~b}$ & $4.74 \mathrm{~b}$ & 18.0 & 8.10 \\
4000 & $6.75 \mathrm{ab}$ & $1.84 \mathrm{~b}$ & $4.90 \mathrm{ab}$ & 17.7 & 8.10 \\
8000 & $6.90 \mathrm{a}$ & $1.97 \mathrm{a}$ & $4.94 \mathrm{a}$ & 17.9 & 8.50 \\
\hline
\end{tabular}

${ }^{1}$ Within columns, means followed by the same letter are not significantly different at $P \leq 0.05$. 
The first humic substances that are formed during earlier stages of composting are the FA. Therefore, high concentration of FA could be associated with an incomplete composting process. The FA, an easily extractable organic carbon, decreases with composting age, and its rate of disappearance depends on the composition of the compost source material (Wu and Ma, 2002). Wu et al. (2002) reported that when concentration of FA drops below $9.4 \mathrm{~g} / \mathrm{kg}$, the evolution of $\mathrm{CO}_{2}$ is very slow, a sign of the compost's stability. The low range of water $(2 \mathrm{~h})$ and $\mathrm{NaOH}$ $(2 \mathrm{~h})$ extractable FA in the samples of this study, 2.2 to $2.6 \mathrm{~g} / \mathrm{kg}$ and 5.8 to $6.3 \mathrm{~g} / \mathrm{kg}$, respectively, and the high concentration of humic acids and cation exchange capacity indicate that the coffee compost pile was mature at the sampling time (Tables 2 and 4).

The structural quality, aliphatic-aromatic, of the HS provides a qualitative index of compost stability. The absorbance of HA extracted with $0.1 \mathrm{M} \mathrm{NaOH}$ for $2 \mathrm{~h}$ and measured at $465 \mathrm{~nm}$ (E4) and $665 \mathrm{~nm}$ (E6), has been used as a qualitative measurement of compost stability (Wu and Ma, 2002). Specifically the E4/E6 ratio provides a tool for estimating relative size of humic substances and humification degree, both of which factors have been directly correlated with aliphatic-aromatic structures (Campitelli and Ceppi, 2008; Tan, 2003). Low E4/E6 ratios indicate greater aromatic carbon networks, whereas high ratios suggest more aliphatic structures and macromolecules of low molecular weight (Tan, 2003; Stevenson, 1994). Over a period of two hours the $\mathrm{NaOH}$-extracted humic acids had low E4/E6 ratios, regardless of particle sizes. This finding indicates the presence of $\mathrm{HA}$ with high molecular weight (Table 5). Humic acids from the largest granular sizes $(8000 \mu \mathrm{m})$ showed the highest $\mathrm{E} 4 / \mathrm{E} 6$ ratio (Table 5), thus indicating HA of lower molecular weight (Cheng et al., 1977; Stevenson, 1994), and also indicating the presence of the relatively largest proportions of aliphatic structures (Senesi et al., 2001) and the least maturity in the largest particles. Thus, low E4/E6 ratios indicate greater aromatic carbon networks, whereas high ratios suggest more aliphatic structures and macromolecules of low molecular weight (Tan, 2003; Stevenson, 1994). The HA extracted with $0.1 \mathrm{M}$ $\mathrm{NaOH}$ for $2 \mathrm{~h}$ from the largest granular sizes $(8000 \mu \mathrm{m})$ had the highest $\mathrm{E} 4 / \mathrm{E} 6$ ratio (Table 5), which indicates the presence of relatively large proportions of aliphatic structures and thus the lowest condensation degree and maturity (Senesi et al., 2001). The smallest ratios were found in the smallest fraction, thereby suggesting greater stable aromatic structures. The above data suggests that differences in the chemical composition of humic substances among particle sizes are associated with intrinsic characteristics of the feedstock rather than with an incomplete composting process. 
This study shows that HS composition and its properties, HS to TOC ratio and labile $\mathrm{C}$ fractions, are related to the size of the particles. The finding of humified organic matter with different $\mathrm{C}$ network properties (aliphatic-aromatic content) helps to explain why the organic amendments usually have short- and long-term agronomic benefits. The short-term benefits of compost come from already mineralized nutrients that provide immediate plant nourishment. Long-term agronomic benefits in part come from better soil structure, porosity and water retention, and the further nutrient mineralization once the organic amendment is applied.

The smallest particle size had the greatest HS/TOC ratio, and lowest E4/E6 ratio and TOC. These findings suggest that during the development of the smaller particles, the increase in superficial area caused an increase in microorganism activity and environmental exposure. As a result, labile $\mathrm{OM}$ and $\mathrm{C}: \mathrm{N}$ ratio decreased, increasing the lability of aliphatic structures and remnants of aromatic structures.

This study demonstrates that 12-month-old coffee pulp compost can be an excellent source of nutrients; these nutrients were generally stable across fractions, with the exception of $\mathrm{K}$. The above data show that CP fractions had up to $65 \%$ organic matter $(\mathrm{TOC} \times 1.68$ ), out of which a maximum of $6.9 \%$ were humic substances. Greater amounts of HA than FA were extracted across all fractions. The larger superficial area of the smallest fractions provides greater exposure to microorganisms and environmental effects thus causing greater decomposition of labile TOC as shown by higher recalcitrant forms, aliphatic-aromatic, HS relative to TOC, and FA-HA amounts. It is suggested that aliphatic-aromatic structure tests should be performed when compost is evaluated, given the fact that FA and HA concentration alone can provide misleading conclusions regarding the long-term effects of OM.

\section{LITERATURE CITED}

Alamo, C .I., M. Monroig, W. González and A. Brugueras, 2006. Manual para la producción y exportación de café en Puerto Rico, Estación Experimental Agrícola, Colegio de Ciencias Agrícola, Universidad de Puerto Rico-Recinto Universitario de Mayagüez.

Amir, S., M. Hafidi, J. R. Bailly and J. C. Revel, 2003. Characterization of humic acids extracted from sewage sludge during composting and of their Sephadex® gel fractions. Agronomie 23:269-275.

Campitelli, P. and S. Ceppi, 2008. Effects of composting technologies on the chemical and physicochemical properties of humic acids. Geoderma 144:325-333.

Chen, Y., N. Senesi and M. Schnitzer, 1977. Information provided on humic substances by E4/E6 ratios. J. Soil Sci. Soc. Am. 41:352-358. 
Chong, J. A., 2009. Aerated Static Pile Construction in Puerto Rico for Coffee Pulp Composting. U.S. Composting Council's 17th Annual Conference \& Tradeshow. http:/ www.compostingcouncil.org/PDF/2009_Proceedings/2009_Proceedings.pdf

Farah, A. and C. M. Donangelo, 2006. Phenolic compounds in coffee. Braz. J. Plant Physiol. 18(1):23-36.

Fischer, M., S. Reimann, V. Trovato and R. J. Redgwell, 2001. Polysaccharides of green Arabica and Robusta coffee beans. Carbohydrate Research 330:93-101.

Marinari, S., K. Liburdi, G. Masciandaro, B. Ceccanti and S. Grego, 2007. Humification mineralization pyrolytic indices and carbon fractions of soil under organic and conventional management in central Italy. Soil \& Tillage Research 92:10-17.

Murkovic, M. and K. Derler, 2006. Analysis of amino acids and carbohydrates in green coffee. J. Biochem. Biophy. Methods 69:25-32.

Nelson, D. W. and L. E. Sommers, 1996. Total carbon, organic carbon and organic matter, p. 995-998. In: D.J. Sparks et al. (ed.). Methods of Soil Analysis, part 3. Chemical Methods. SSSA Book Ser, 5 SSSA a.

Senesi, N., E. Loffredo, V. D'Orazio, G. Brunetti and T. M. Miano, 2001. In: Humic Substance and Chemical Contaminants. Ed. Clapp C. E., M. N. B. Hayes. N. Senesi, P. R. Bloom and P. M. Jandine. Soil Science Society of America, Inc. 677S. Segoe Rd., Madison, WI 53711.

Stevenson, F. J., 1994. Humus Chemistry: Genesis, composition, reactions. John Wiley \& Sons, Inc. New York, 2nd ed.

Tan, K. H., 2003. Humic Matter in Soil and the Environment: Principles and Controversies. MarcelDekker, Inc., New York, ISBN: 0-8247-4272-9, pp: 39.

Ulloa-Rojas, J. B., J. A. J. Verreth, S. Amato and E. A. Huisman, 2003. Biological treatments affect the chemical composition of coffee pulp. Bioresources Technology 89:267-274.

Wu, L. and L. Q. Ma, 2002. Relationship between compost stability and extractable organic carbon. J. Environ. Qual. 31:1323-1328. 
